\title{
First record of a representative of the subfamily Paradiaptominae (Copepoda Calanoida Diaptomidae) in Italy: Metadiaptomus chevreuxi (Guerne \& Richard, 1894)
}

\author{
Federico MARRONE* and Luigi NASELLI-FLORES \\ Dipartimento di Scienze Botaniche, Università di Palermo, Via Archirafi, 38 - 90123 Palermo, Italy \\ *e-mail corresponding author: federico.marrone@neomedia.it
}

\begin{abstract}
Metadiaptomus chevreuxi (Guerne \& Richard 1894), a diaptomid calanoid copepod belonging to the subfamily Paradiaptominae, has been found in two neighbouring temporary pools in the Egadi Archipelago (Sicily, southern Italy). This finding constitutes the first record of a representative of this subfamily in Italy and the second known European record for this species. M. chevreuxi, commonly found in the arid areas of Maghreb, has already been reported to occur in Mallorca Island (Balearic Archipelago, Spain), while it seems to be rare in the eastern quadrants of the Mediterranean basin. The characteristics of the new Italian site are briefly described and drawings of morphological details of adult specimens are provided. The occurrence of M. chevreuxi in Western Sicily is in accordance with the supposed merging of North-eastern and South-western freshwater calanoid faunas in this area. Additional information on the distribution of calanoid species in the island and its biogeographic significance is also offered.
\end{abstract}

Key-words: Calanoida, Paradiaptominae, Mediterranean basin, Sicily, distribution

\section{INTRODUCTION}

The Paradiaptominae (Copepoda, Calanoida) is a small group of Gondwanian origin belonging to the large family Diaptomidae. About 24 species, mainly confined in temporary or semi-permanent water bodies of arid regions, belong to this subfamily. Metadiaptomus Methuen, 1910 is the most speciose genus of the subfamily, with 10 described species, followed by Paradiaptomus Sars, 1895, with 9 species. Most of these species have a Sub-Saharian distribution (Rayner 2000).

Only four Paradiaptominae species are known to occur also outside Africa: Metadiaptomus asiaticus (Ul'yanin, 1875), M. chevreuxi (Guerne \& Richard 1894), Paradiaptomus greeni (Gurney 1906), and Neolovenula alluaudi (Guerne \& Richard 1890). Two of these species, $N$. alluaudi and $M$. chevreuxi, are also known from Europe (Jaume 1989; Dussart \& Defaye 2002) but they were never recorded in Italy up to now. The present note reports the finding of Metadiaptomus chevreuxi in Sicily (southern Italy), which thus represents the first finding of a representative of the whole subfamily Paradiaptominae in Italy.

M. chevreuxi is common in areas characterized by low precipitation values $\left(<500 \mathrm{~mm} \mathrm{y}^{-1}\right)$ and becomes rarer and rarer along a humidity gradient to disappear at precipitation values higher than $500 \mathrm{~mm} \mathrm{y}^{-1}$ (Kiefer 1978a; Dumont et al. 1979; Ramdani 1988; Turki \& El Abed 1999). It is typical of the steppic and substeppic areas of Maghreb and Middle East (Rayner 2000). The occurrence of $M$. chevreuxi in Middle East (Iran and Iraq) is reported by Gurney (1921), whereas Dumont (1979) found it in two sites in Jordan. According to our knowledge, no further reports of this species are available for that area and, in spite of the presence of suitable habitats, its occurrence has not been reported for Egypt (Kiefer 1978b) and Israel (Dimentman \& Por 1985). Moreover, the distribution of a calanoid species, especially if it occurs in temporary waters may be easily overlooked. Also, especially in Africa, collection of freshwater invertebrates is not easy. Distances are great and some areas in drier regions are just not easily accessible (Rayner, pers. comm.).

Actually, in spite of recent contributes and reviews (e.g. Mouehli et al. 2000; Dussart \& Defaye 2002), the freshwater calanoid faunas from Western Mediterranean countries is far from being adequately known, and many areas still remain unexplored. This situation prevents from establishing a clear picture of the distribution patterns of several species and, as a consequence, of the affinities and mutual influences among the faunas of circum-Mediterranean countries. To fill this gap, more numerous and detailed studies are desirable.

\section{MATERIAL AND METHODS}

The study material was collected on January 22, 2005 in Favignana Island (Egadi Archipelago, Western Sicily, Southern Italy) in two neighbouring, a few centimetres deep, temporary pools close to the seashore (Pozze dell'Uccerì: UTM WGS84 coordinates 4203663 N, 33262890 E; altitude $3 \mathrm{~m}$ a.s.1.). 


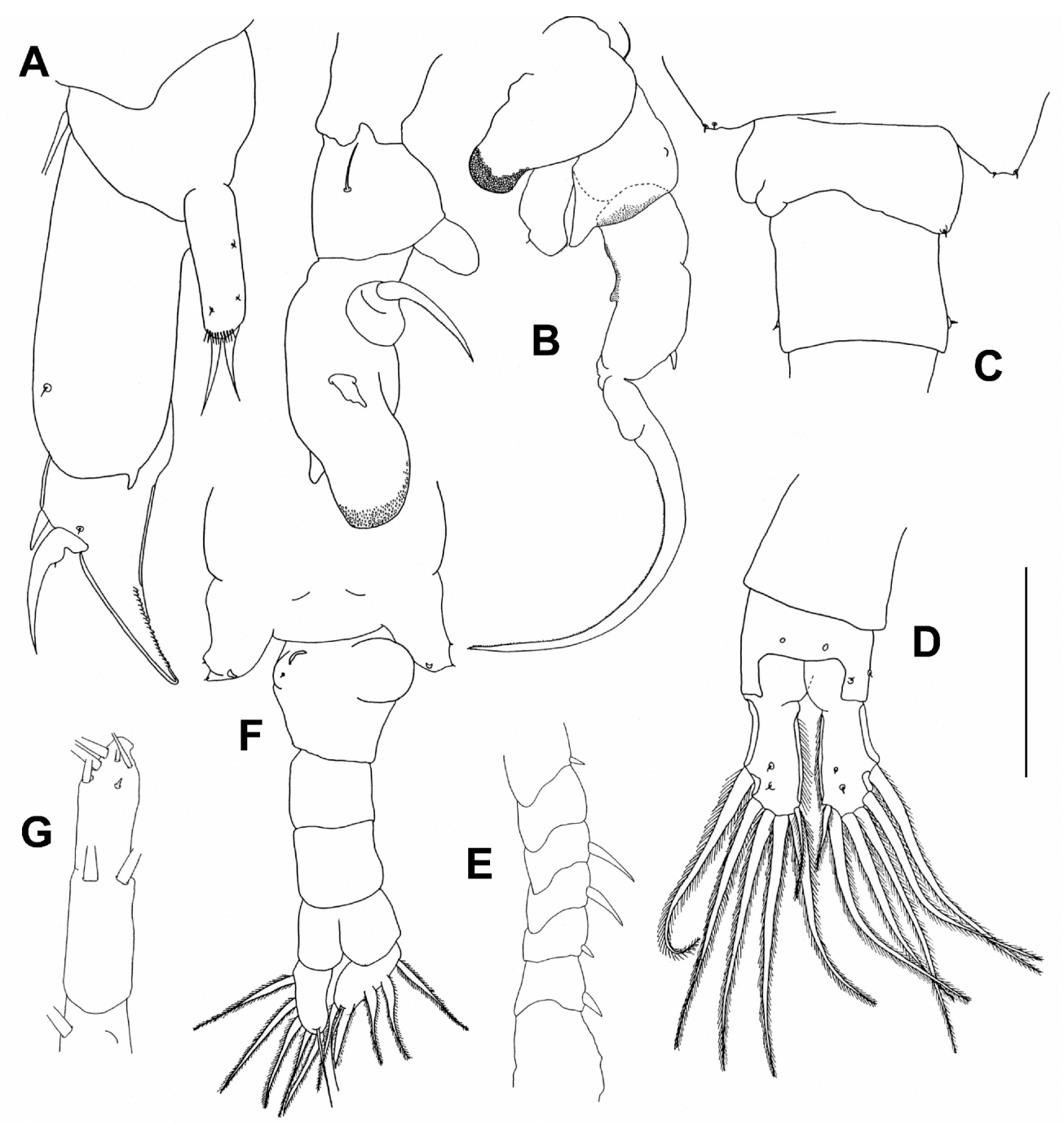

Fig. 1. A, F: Metadiaptomus chevreuxi, female. A: P5; F: somites 4, 5 and urosome, dorsal view. B, C, D, E, G: M. chevreuxi, male. B: P5; C: somite 5 and urosomites 1, 2; D: furca; E: right antennula, segments 8-14; G: right antennula, segments 19-21. Scale bar, A: $125 \mu \mathrm{m} ; \mathbf{B}, \mathbf{C}, \mathbf{D}, \mathbf{E}: 250 \mu \mathrm{m} ; \mathbf{F}: 500 \mu \mathrm{m} ; \mathbf{G}: 100 \mu \mathrm{m}$.

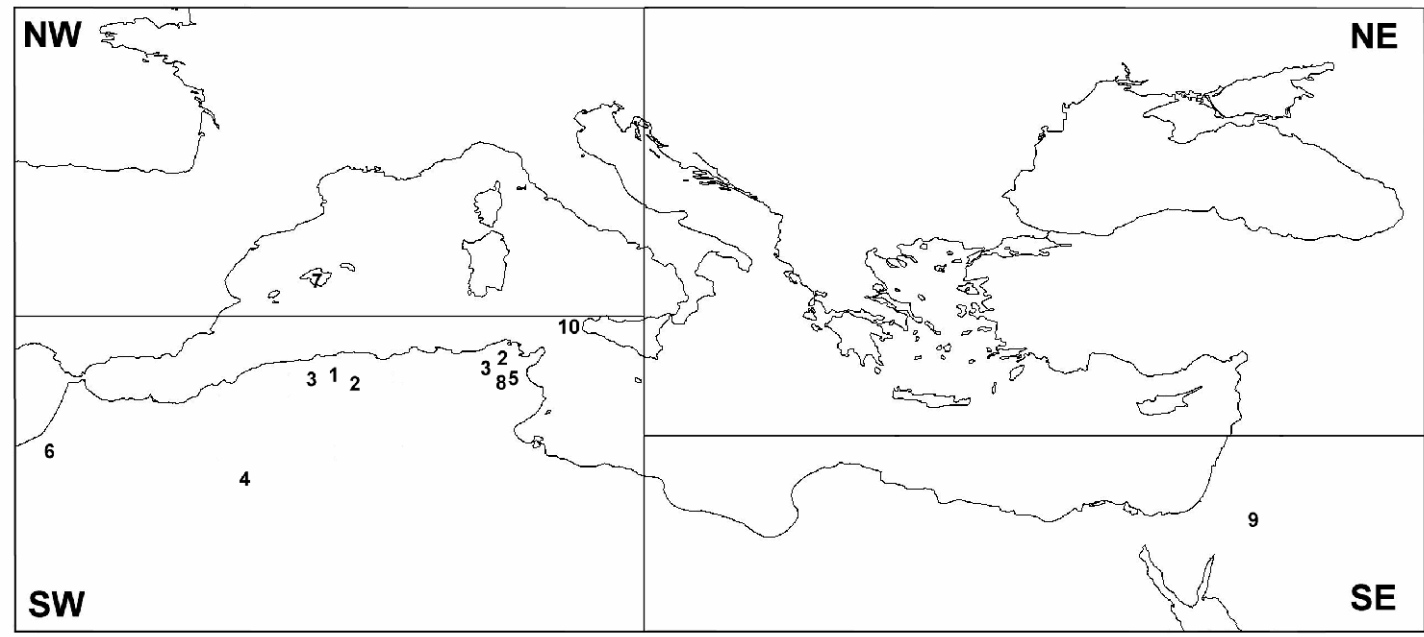

Fig. 2. Distribution of Metadiaptomus chevreuxi in the circum-Mediterranean area. 1: Gurney 1909; 2: Roy \& Gauthier 1927; 3: Gauthier 1928; 4: Gauthier 1931; 5: Dumont et al. 1979; 6: Ramdani 1988; 7: Jaume 1989; 8: Turki \& El Abed 1999; 9: Dumont 1979; 10: Present paper. The Mediterranean Sea is divided in four biological quadrants according to Blondel \& Aronson (1999). 
Indeed the site, at its maximum holding, is formed by only one pond with a surface of about 3.5 ha which divides into several smaller ponds when its surface reduces.

In Trapani meteorological station, located on Sicilian mainland $15 \mathrm{~km}$ far from Favignana Island, the average annual rainfall is $483 \mathrm{~mm}$ and the average temperature is $18{ }^{\circ} \mathrm{C}$ (Zampino et al. 1997). Thus, Favignana Island can be considered as a substeppic zone according to Gauthier (1928) and Turki \& El Abed (1999).

Water temperature, conductivity and $\mathrm{pH}$ were registered with an Hanna Instruments HI 13110 multiprobe.

Microcrustacean samples were collected by means of a $200 \mu \mathrm{m}$ hand net and fixed in situ with $4 \%$ buffered formaldehyde. Calanoid copepods were sorted and dissected under an Optika dissecting microscope and identified to the species level according to Kiefer (1978a), Dussart (1989) and Rayner (1999). Drawings of selected specimens were realized with an Olympus CX41 microscope equipped with a camera lucida after tissue clearing in hot lactic acid. Preserved specimens are stored in the authors' collection.

\section{RESULTS AND DISCUSSION}

In the frame of a faunal survey aimed at getting a better knowledge of the entomostracan fauna of Sicily (southern Italy), a thriving population of the Paradiaptominae Metadiaptomus chevreuxi was found on Favignana Island (Egadi Island, western Sicily).

At the sampling date, the pond was divided into two basins, both characterised by extremely turbid waters due to suspended clay. Electric conductivity, $\mathrm{pH}$ and water temperature had similar values in both the ponds (920-915 $\mu \mathrm{S} \mathrm{cm}{ }^{-1}, 8.07-8.10,19.3-19.5{ }^{\circ} \mathrm{C}$, respectively).

In the sample, both adult and immature specimens of $M$. chevreuxi co-occurred with adult specimens of Triops cancriformis cancriformis (Bosc, 1802), Branchipus schaefferi Fischer, 1834, Daphnia (Ctenodaphnia) atkinsoni Baird, 1859 (Branchiopoda), Ilyocypris decipiens Masi, 1905, Eucypris virens (Jurine 1820), Tonnacypris lutaria (Koch 1838), Heterocypris incongruens (Ramdohr 1808) (Ostracoda), unidentified copepodids of cyclopoid copepods and heteropteran insects belonging to the genera Corixa and Notonecta. No other calanoid species were found in the Favignana island nor in the other islands of the Egadi Archipelago.

Rayner (1999) stressed that the representatives of the Paradiaptominae are morphologically very stable, with well defined taxonomic characters. Adults from Favignana (Fig. 1) can undoubtedly be attributed to the species Metadiaptomus chevreuxi according to the drawings by Kiefer (1978a) and to the descriptions also reported by Dussart (1989) and Rayner (1999), but differ in the number of setae on the furca from those represented in the figure $5 \mathrm{~A}$ in the paper by Jaume (1989).
The occurrence of $M$. chevreuxi in Favignana is in agreement with the supposed merging of North-eastern and South-western Mediterranean freshwater calanoid faunas in Sicily (Marrone et al. in press) due to the island location in the middle of the basin, in between the SW and NE quadrants (Fig. 2) as described by Blondel \& Aronson (1999). Recent faunal surveys, aimed at getting a better knowledge of the microcrustacean fauna of this nodal point for the faunal interchange in the basin (e.g. Naselli-Flores et al. 1998; Marrone 2003; Marrone \& Naselli-Flores 2004), show that freshwater calanoid copepods distribution clearly reflects the rather complex geological history of the Mediterranean basin. As well as for the flora of the island, several south-western and north-eastern influences can be highlighted strictly depending on historical and ecological factors (Francini \& Messeri 1956). As partially described in a previous note (Marrone \& Naselli-Flores 2004), the typically NorthAfrican and West-Mediterranean taxa Hemidiaptomus ingens and $M$. chevreuxi inhabit only the dryer areas of the western part of Sicily. Conversely, the temperate and eastern-gravitating Diaptomus serbicus Gjorgjewič, 1907, Arctodiaptomus kerkyrensis (Pesta 1935) and, secondarily, Arctodiaptomus stephanidesi (Pesta 1935) show an east-west gradient which follows the mesic siliceous outcrops of the Nebrodi and Sicani Mountains, where these species are found only at an altitude above $800 \mathrm{~m}$ a.s.l., often along with Mixodiaptomus kupelwieseri (Brehm 1907) and Hemidiaptomus gurneyi (Roy 1927). Other calanoid species, like Diaptomus cyaneus Gurney 1909, Copidodiaptomus numidicus (Gurney 1909), Arctodiaptomus salinus (Daday 1885) and Calanipeda aquaedulcis Kritschagin, 1873 are widespread in the region (Marrone et al. 2005), as well as in all the circumMediterranean countries, and their even distribution in the island is linked to some environmental characteristic as salinity, hydroperiod and depth.

\section{ACKNOWLEDGMENTS}

Valentina Pieri is warmly acknowledged for ostracods identification. We wish to express our gratitude to Giampaolo Rossetti, Fabio Stoch and Henri Dumont who gave suggestions and advices which improved an earlier draft of the note.

\section{REFERENCES}

Blondel, J. \& J. Aronson. 1999. Biology and Wildlife of the Mediterranean Region. Oxford University Press, Oxford New York: 328 pp.

Dimentman, C. \& F.D. Por. 1985. Diaptomidae (Copepoda, Calanoida) of Israel and Northern Sinai. Hydrobiologia, 127: 89-95.

Dumont, H.J. 1979. Limnologie van Sahara en Sahel. D. Sci. thesis, Rijksuniv. Gent: $557 \mathrm{pp}$.

Dumont, H.J., P. Laureys \& J. Pensaert. 1979. Anostraca, Conchostraca, Cladocera and Copepoda from Tunisia. Hydrobiologia, 66: 259-274.

Dussart, B.H. 1989. Crustacés copépodes des eaux intérieures Africaines. Crustaceana, Suppl. 15. Leiden, Brill.: 205 pp. 
Dussart, B. \& D. Defaye. 2002. World directory of Crustacea Copepoda of inland waters. I. Calaniformes. Backuhys Publishers, Leiden: 276 pp.

Francini, E. \& A. Messeri. 1956. L'isola di Marettimo nell'arcipelago delle Egadi e la sua vegetazione. Webbia, 11: $607-846$.

Gauthier, H. 1928. Recherches sur la faune des eaux continentales de l'Algérie et de la Tunisie. Thése Sciences, Alger, Minerva: 419 pp.

Gauthier, H. 1931. Faune aquatique du Sahara central. Récoltes de M. L. G. Seurat au Hoggar en 1928. Bull. Soc. Nat. Afr. N., 22: 350-400.

Gurney, R. 1909. On the Fresh-water Crustacea of Algeria and Tunisia. J. R. microscop. Soc., 443: 273-305.

Gurney, R. 1921. Fresh-water Crustacea collected by Dr. P.A. Buxton in Mesopotamia and Persia. J. Bombay nat. hist. soc., 27(4): 85-93.

Kiefer, F. 1978a. Das Zooplankton der Binnengewaesser Freilebende Copepoda. Die Binnengewaesser, Band 26 Teil 2. E. Schweizerbart'sche Verlagbuchhandlung, Stuttgart: $343 \mathrm{pp}$.

Kiefer, F. 1978b. Zur Kenntnis der Copepodenfauna aegyptischer Binnengewaesser. Arch. Hydrobiol., 84(4): 480-499.

Jaume, D. 1989. Metadiaptomus chevreuxi (Copepoda: Calanoida: Diaptomidae) and Leptestheria mayeti (Branchiopoda: Conchostraca: Leptestheriidae), two African freshwater crustaceans recorded in Majorca. Limnetica, 5: 101109.

Marrone, F. 2003. On some cladocerans new to Sicily (Southern Italy) (Crustacea Branchiopoda). Naturalista sicil., 27: 263-270.

Marrone, F. \& L. Naselli Flores. 2004. First record and morphological features of Hemidiaptomus (Occidodiaptomus) ingens (Gurney, 1909) (Copepoda Calanoida) in Italy. J. Limnol., 63 (2): 250-255.

Received: March 2005

Accepted: April 2005
Marrone, F., G. Castelli, R. Barone \& L. Naselli Flores. (2005). Ecology and distribution of calanoid copepods in Sicilian inland waters (Italy). Verh. int. Ver. Limnol., 29: (in press).

Mouelhi, S., G. Balvay \& M.M. Kraiem. 2000. Branchiopodes (Cténopodes et Anomopodes) et Copépodes des eaux continentales d'Afrique du Nord: inventare et biodiversité. Zoosystema, 22(4): 731-748.

Naselli-Flores, L., R. Barone \& M. Zunino. 1998. Distribution patterns of freshwater zooplankton in Sicily (Italy). Verh. int. Ver. Limnol., 26: 1973-1980.

Ramdani, M. 1988. Les eaux stagnantes du Maroc: études biotypologique et biogéographique $\mathrm{du}$ zooplancton. Travaux de l'Institut Scientifique, Série Zoologie, Rabat, 43: $40 \mathrm{pp}$.

Rayner, N.A. 1999. Copepoda: Calanoida (Diaptomidae: Paradiaptomidae). Guides to the identification of the Microinvertebrates of the Continental Waters of the World. Backhuys Publishers, Leiden: $122 \mathrm{pp}$.

Rayner, N. A. 2000. Distribution and biogeography of the Paradiaptominae (Copepoda: Calanoida: Diaptomidae). Afr. J. aquat. Sci., 25: 93-97.

Roy, J. \& H. Gauthier. 1927. Sur les copépodes d'Algérie et Tunisie (eaux douces et eaux saumâtres). Bull. Soc. Zool. France, 52: 558-575.

Turki, S. \& A. El Abed. 1999. Nouvelles informations sur les copépodes calanoïdes et cyclopoïdes des eaux continentals tunisiennes. Crustaceana, 72(2): 157-169.

Zampino, D., A. Duro, V. Piccione \& C. Scalia. 1997. Fitoclima della Sicilia. Termoudogrammi secondo Walter e Lieth. In: E. Guerrini (Ed.), Atti V Workshop "Progetto Strategico Clima, Ambiente e Territorio nel Mezzogiorno". Vol II: 7-54. 